\title{
Genomic Profiling: The Strengths and Limitations of Chloroplast Genome- Based Plant Variety Authentication
}

Doreen Teske ${ }^{1}$, Alina Peters ${ }^{1}$, Alexander Möllers ${ }^{1}$, Markus Fischer ${ }^{1, *}$

${ }^{1}$ Hamburg School of Food Science, Institute of Food Chemistry, University of Hamburg, Grindelallee 117, 20146 Hamburg, Germany

*Corresponding Author

markus.fischer@uni-hamburg.de; Phone: +49 4042838 4359; Fax: +49 40428384342

\section{Contents}

Part I. Supplemental Tables

Table S1: Publicly available plastid sequences (NCBI nucleotide database).

Table S2: Comparison of chloroplast and DNA isolation methods.

Table S3: Sequences derived from different walnut varieties (Statistics of in house NGS analysis).

Part II. Supplemental Figures

Figure S1. Modern cultivars using the example of walnut.

Part III. Supplemental methods and materials

Method S1. Plant Material Handling

Method S2. The isolation of the chloroplasts

Method S3. The isolation of the cpDNA

Method S4. Quality control and quantitation of the isolated DNA

Method S5. Library preparation and sequencing

Method S6. Data processing and assembly 
Part I. Supplemental Tables

Table S1: Publicly available plastid sequences (NCBI nucleotide database), date of request November 13, 2019.

\begin{tabular}{|c|c|}
\hline ORGANISM & NCBI ACCESSION NUMBER \\
\hline CANNABIS SATIVA SUBSP. SATIVA CULTIVAR CHEUGSAM & KR184827 \\
\hline CANNABIS SATIVA SUBSP. SATIVA CULTIVAR YORUBA NIGERIA & KR363961 \\
\hline JUGLANS REGIA CULTIVAR BROADVIEW & MN397924 \\
\hline JUGLANS REGIA CULTIVAR CHANDLER & MN397925 \\
\hline JUGLANS REGIA CULTIVAR FERNETTE & MN397926 \\
\hline JUGLANS REGIA CULTIVAR FERNOR & MN397927 \\
\hline JUGLANS REGIA CULTIVAR FRANQUETTE & MN397928 \\
\hline JUGLANS REGIA CULTIVAR GEISENHEIM 26 & MN397929 \\
\hline JUGLANS REGIA CULTIVAR HARTLEY & MN397930 \\
\hline JUGLANS REGIA CULTIVAR HOWARD & MN397931 \\
\hline JUGLANS REGIA CULTIVAR LARA & MN397932 \\
\hline JUGLANS REGIA CULTIVAR PEDRO & MN397933 \\
\hline JUGLANS REGIA CULTIVAR SERR & MN397934 \\
\hline JUGLANS REGIA CULTIVAR VINA & MN397935 \\
\hline JUGLANS REGIA & KT963008 \\
\hline OLEA EUROPEA CULTIVAR FRANTOIO & GU931818 \\
\hline OLEA EUROPEA CULTIVAR BIANCHERA & NC_013707 \\
\hline ORYZA SATIVA CULTIVAR PA64S & AY522331 \\
\hline ORYZA SATIVA CULTIVAR 93-11 & AY522329 \\
\hline PHOENIX DACTYLIFERA CULTIVAR ASEEL & FJ212316 \\
\hline PHOENIX DACTYLIFERA CULTIVAR KHALAS & GU811709 \\
\hline PHOENIX DACTYLIFERA CULTIVAR KHANEZI & MF197494 \\
\hline PHOENIX DACTYLIFERA CULTIVAR NAGHAL & MF197495 \\
\hline SOLANUM LYCOPERSICUM CULTIVAR IPA-6 & AM087200 \\
\hline THEOBROMA CACAO & HQ244500 \\
\hline THEOBROMA CACAO GENOTYPE CRIOLLO-22 & JQ228379 \\
\hline THEOBROMA CACAO GENOTYPE AMELONADO & JQ228380 \\
\hline THEOBROMA CACAO GENOTYPE ICS-01 & JQ228381 \\
\hline THEOBROMA CACAO GENOTYPE SCAVINA-6 & JQ228382 \\
\hline THEOBROMA CACAO GENOTYPE ICS-06 & $J Q 228383$ \\
\hline THEOBROMA CACAO GENOTYPE EET-64 & $J Q 228384$ \\
\hline THEOBROMA CACAO GENOTYPE STAHEL & $J Q 228385$ \\
\hline THEOBROMA CACAO GENOTYPE PENTAGONUM & JQ228386 \\
\hline THEOBROMA CACAO GENOTYPE ICS-39 & JQ228387 \\
\hline THEOBROMA GRANDIFLORUM & JQ228388 \\
\hline THEOBROMA CACAO & JQ228389 \\
\hline
\end{tabular}


Table S2: Comparison of chloroplast and DNA isolation methods.

ORGANISM

\begin{tabular}{|c|c|}
\hline CANNABIS SATIVA $^{1}$ & $\begin{array}{l}\text { Minute }^{\mathrm{TM}} \text { Chloroplast Isolation Kit } \\
\text { (Invent) }\end{array}$ \\
\hline JUGLANS REGIA ${ }^{2}$ & $\begin{array}{l}\text { leaves ground by dispersion tool } \\
\left(0^{\circ} \mathrm{C}\right) \\
\text { Buffer: sorbitol, Tris, EDTA, PVP, } \\
\text { B-mercaptoethanol } \\
\text { filtration and centrifugation steps }\end{array}$ \\
\hline OLEA EUROPEA ${ }^{3}$ & - \\
\hline ORYZA SATIVA ${ }^{4}$ & $\begin{array}{l}\text { leaves ground by mortar and pestle }\left(0^{\circ} \mathrm{C}\right) \\
\text { Buffer: sucrose, Tris, EDTA, BSA, } \\
\text { B-mercaptoethanol } \\
\text { filtration and centrifugation steps } \\
\text { DNase treatment }\end{array}$ \\
\hline
\end{tabular}

PHOENIX DACTYLIFERA ${ }^{5}$

PHOENIX DACTYLIFERA ${ }^{6}$

SOLANUM

LYCOPERSICUM ${ }^{7}$

THEOBROMA CACAO ${ }^{8,9}$

\section{CHLOROPLAST ISOLATION}

DNase treatment

leaves ground by mortar and pestle $\left(0^{\circ} \mathrm{C}\right)$

Buffer: sucrose, Tris, EDTA, BSA,

ß-mercaptoethanol

filtration and centrifugation steps

DNase treatment

leaves ground by liquid nitrogen and

mortar + pestle

Buffer: Tris, $\mathrm{KCl}, \mathrm{EDTA}$, spermidine, spermine, sucrose, ß-mercaptoethanol filtration and centrifugation steps leaves ground by waring blender $\left(4^{\circ} \mathrm{C}\right)$ Buffer: sorbitol, Tris, EDTA, ß-mercaptoethanol, BSA filtration and centrifugation steps sucrose gradient with 6 layers
DNA ISOLATION

RED-Extract-N-Amp Tissue PCR Kit (Sigma)

lysis with $\mathrm{CTAB}$

chloroform extraction

purification with silica column

wash with ethanol

DNeasy Plant Mini kit (Qiagen)

lysis with SDS

phenol/chloroform extraction wash with ß-mercaptoethanol precipitation with ammonium acetate + isopropanol

\section{lysis with SDS}

phenol/chloroform extraction wash with ß-mercaptoethanol precipitation with ammonium acetate + isopropanol

lysis with $\mathrm{CTAB}$

phenol/chloroform extraction wash with ethanol

precipitation with isopropanol

lysis with n-lauroylsacosine phenol/chloroform extraction precipitation with ethanol

DNeasy Plant Mini kit (Qiagen) 
Table S3: Sequences derived from different walnut varieties (Statistics of in house NGS analysis using an Illumina MiSeq sequencing platform) ${ }^{2}$.

\begin{tabular}{l|llllll} 
CULTIVAR & $\begin{array}{l}\text { ACCESSION } \\
\text { NUMBER }\end{array}$ & $\begin{array}{l}\text { TOTAL } \\
\text { PAIRED } \\
\text { END READS }\end{array}$ & $\begin{array}{l}\text { MAPPED } \\
\text { READS }\end{array}$ & $\begin{array}{l}\text { MAPPED } \\
\text { READS } \\
{[\%]}\end{array}$ & $\begin{array}{l}\text { AVERAGE } \\
\text { COVERAGE }\end{array}$ & $\begin{array}{l}\text { \% OF } \\
\text { CHLOROPLAST } \\
\text { SEQUENCED }\end{array}$ \\
\hline BROADVIEW & MN397924 & 1091176 & 46264 & 4.24 & $36.4 \pm 14.9$ & 100 \\
CHANDLER & MN397925 & 497860 & 20830 & 4.18 & $17.8 \pm 8.3$ & 100 \\
FERNETTE & MN397926 & 22784032 & 1359027 & 5.96 & $1118 \pm 419$ & 100 \\
FERNOR & MN397927 & 1164818 & 45554 & 3.91 & $37.2 \pm 19.4$ & 100 \\
FRANQUETTE & MN397928 & 443042 & 25590 & 5.78 & $22.3 \pm 10.2$ & 100 \\
GEISENHEIM 26 & MN397929 & 1270004 & 28771 & 2.27 & $22.7 \pm 11.5$ & 100 \\
HARTLEY & $M N 397930$ & 1339334 & 61765 & 4.61 & $50.3 \pm 18.0$ & 100 \\
HOWARD & $M N 397931$ & 1049592 & 629358 & 59.9 & $529 \pm 234$ & 100 \\
LARA & $M N 397932$ & 1108086 & 59156 & 5.34 & $46.9 \pm 18.0$ & 100 \\
PEDRO & $M N 397933$ & 1180994 & 53216 & 4.51 & $42.9 \pm 26.3$ & 100 \\
SERR & $M N 397934$ & 1124886 & 78267 & 6.96 & $63.2 \pm 22.9$ & 100 \\
VINA & $M N 397935$ & 1266008 & 42894 & 3.39 & $34.3 \pm 23.3$ & 100
\end{tabular}




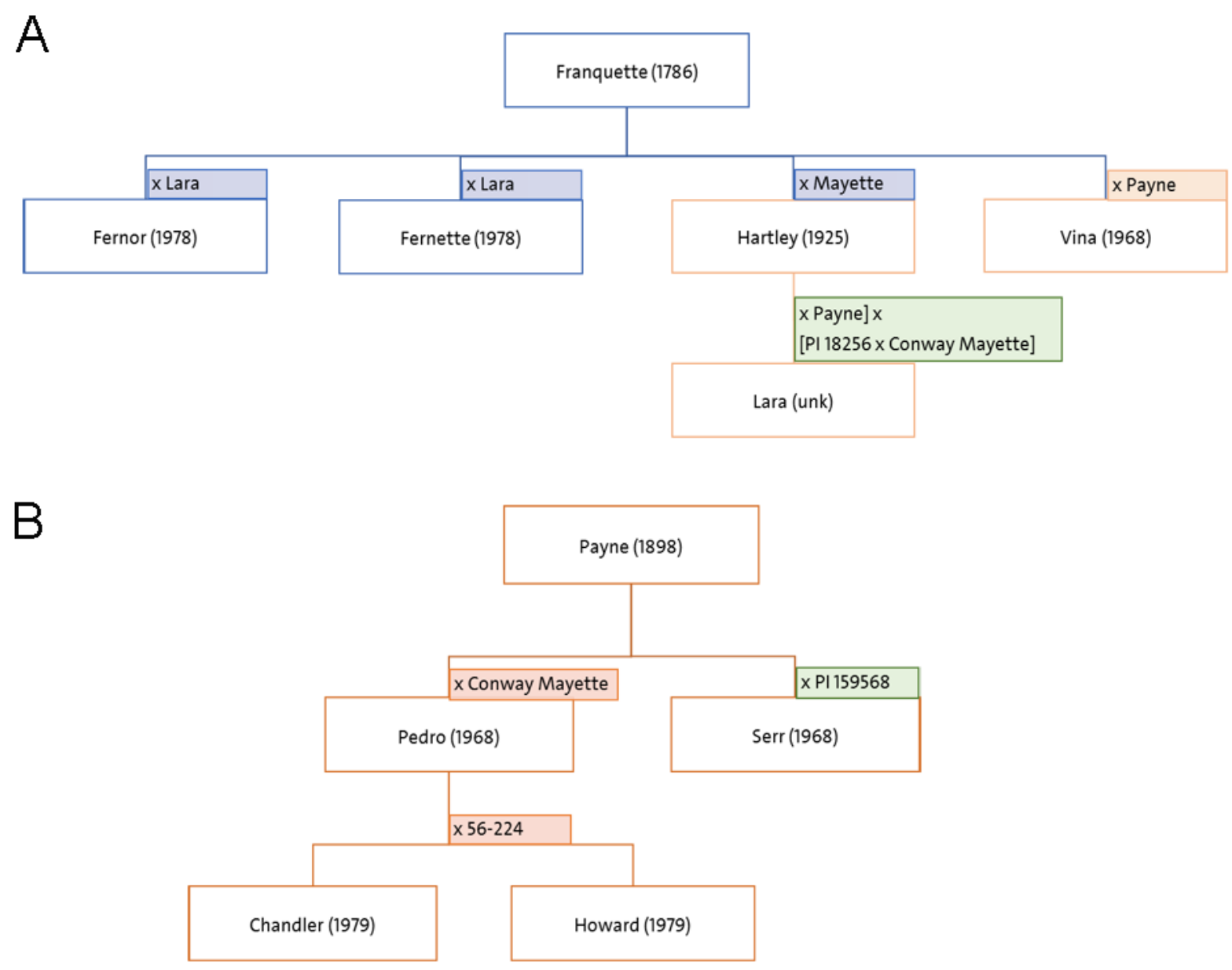

Figure S1. Modern cultivars using the example of walnut. Pedigree from common walnut cultivars deduced from breeding history. ${ }^{10-13}$ The orange boxes symbolize cultivars developed in the USA. The blue boxes symbolize cultivars developed in France, besides the green boxes are a mixture of cultivars from different origins. The cultivars Broadview and Geisenheim 26 have another breeding background. Broadview was breed in Canada; the Geisenheim 26 is a German chance seedling. A. This genealogy tree shows all the cultivars, which are descended from the old French cultivar Franquette. B. This genealogy tree shows all the cultivars, which are descended from the Californian cultivar Payne. 


\section{Part III. Supplemental methods and materials}

Method S1. Plant Material Handling

Leaves from 12 walnut cultivars from different geographic locations originated from walnut plantations and breeding facilities. In total, samples from 24 grafted walnut trees with authentic identity were achieved. For the cultivar Howard, only three nut samples from different locations and only one sample of Fernette have been obtained. The sampled fresh leaves/nuts have been stored at $-20^{\circ} \mathrm{C}$. For the sample preparation, the leaves were washed with $1 \% \mathrm{NaOH}$ solution for $30 \mathrm{sec}$ to reduce the microbial contamination, followed by a washing step using distilled water for $5 \mathrm{~min}$ and $70 \%$ ethanol $(\mathrm{v} / \mathrm{v})$ for $10 \mathrm{~min}$. The leave midrib was removed and the leaves cut into small pieces (approximately $3 \times 3 \mathrm{~cm}$ ).

Method S2. The isolation of the chloroplasts

The process was based on the publication of Lang et al. ${ }^{14} \mathrm{All}$ the following steps were carried out at $4{ }^{\circ} \mathrm{C}$ if not otherwise mentioned.

For the isolation $10 \mathrm{~g}$ of frozen leaf material $\left(-20^{\circ} \mathrm{C}\right)$, which was freed from the midrib and divided into approximately $1 \mathrm{~cm}^{2}$ large pieces was used. These were placed in a metal cylinder and suspended with $200 \mathrm{~mL}$ isolation buffer (300 mM sorbitol, $13 \mathrm{mM}$ Tris- $\mathrm{HCl}, 20 \mathrm{mM}$ MOPS, $1 \%$ PVP, $0.1 \%$ ßmercaptoethanol, $\mathrm{pH} 7.8,4^{\circ} \mathrm{C}$ ). Additionally, $10 \mathrm{~g}$ seeds were ground and incubated overnight with $200 \mathrm{~mL}$ isolation buffer. The further processing of the two materials was done analogously. The sample was homogenized for $90 \mathrm{~s}$ at high speed using an Ultra-Turrax ${ }^{\circledR}$ (IKA, model: T 18). The suspension was filtered twice through a Miracloth filter and centrifuged at $200 \times \mathrm{g}$ for $5 \mathrm{~min}$. The supernatant was transferred and centrifuged at $3000 \times \mathrm{g}$ for $15 \mathrm{~min}$. The supernatant was discarded and the pellet resuspended in $500 \mu \mathrm{L}$ wash buffer ( $300 \mathrm{mM}$ sorbitol, $2 \mathrm{mM}$ EDTA, $\mathrm{pH} 7.8,4^{\circ} \mathrm{C}$ ). The suspension was transferred to a discontinuous Percoll ${ }^{\mathrm{TM}}$ gradient $(20 \% / 40 \% / 60 \%)$ and divided into three gradients. Centrifugation was performed at $16.000 \mathrm{x}$ g for $1 \mathrm{~h}$ using a swing-out rotor (BeckmanCoulter, Model: SW $40 \mathrm{Ti}$ ) and an ultracentrifuge (BeckmanCoulter, Model: Optima XE). The bands were carefully removed at the phase boundary using a pasteur pipette, combined and $30 \mathrm{~mL}$ wash buffer was added. The suspension was centrifuged at $3000 \times \mathrm{g}$ for $40 \mathrm{~min}$. The supernatant was discarded and the pellet resuspended in $500 \mu \mathrm{L}$ ultrapure water and was used for the isolation of the DNA.

Method S3. The isolation of the cpDNA

$150 \mathrm{mg}$ of the suspension was transferred into a 2-mL-tube and $1 \mathrm{ml}$ isolation buffer ( $55 \mathrm{mM} \mathrm{CTAB}$, 1.4 M NaCl, $0.1 \mathrm{M}$ Tris- $\mathrm{HCl}, 20 \mathrm{mM}$ EDTA) was added and the suspension was gently inverted several times. The suspension was incubated at $250 \times \mathrm{g}$ for $1 \mathrm{~h}$ at $65^{\circ} \mathrm{C}$ by gently shaking. Afterwards, $700 \mu \mathrm{L}$ 
chloroform was added and gently homogenized. The suspension was centrifuged at $10,000 \times \mathrm{g}$ for $10 \mathrm{~min}$ and $800 \mu \mathrm{L}$ of the supernatant was transferred to a 1.5-mL-tube. The extraction step with chloroform was repeated and the centrifugation was shortened to $5 \mathrm{~min} .700 \mu \mathrm{L}$ of the supernatant was pipetted into a $1.5 \mathrm{~mL}$ tube, $700 \mu \mathrm{L}$ isopropanol $\left(-20^{\circ} \mathrm{C}\right)$ was added and homogenized. The suspension was incubated for $30 \mathrm{~min}$ at $-20^{\circ} \mathrm{C}$ and then centrifuged at $10,000 \mathrm{~g}$ for $10 \mathrm{~min}$. The supernatant was discarded, while the pellet was dissolved in $650 \mu \mathrm{L}$ binding buffer (5,5 M guanidine hydrochloride, $20 \mathrm{mM}$ Tris- $\mathrm{HCl}, \mathrm{pH}$ 6.6). The solution was pipetted into an EconoSpin ${ }^{\circledR}$ column (epochlifescience), also transferring insoluble components. After centrifugation at 10,000 x g for $2 \mathrm{~min}$, the filtrate was discarded and the column was washed with $600 \mu \mathrm{L}$ wash buffer $(20 \mathrm{mM}$ Tris- $\mathrm{HCl}, 1 \mathrm{mM}$ EDTA, $50 \mathrm{mM} \mathrm{NaCl}$, in $50 \%$ ethanol, $\mathrm{pH}$ 7.4). This was followed by a further wash step with $500 \mu \mathrm{L}$ $70 \%$ ethanol $\left(-20^{\circ} \mathrm{C}\right)$. Between each washing step, centrifugation was performed at $12,000 \times \mathrm{g}$ for $2 \mathrm{~min}$ and the filtrate was discarded. Finally, the column with the cpDNA was dried at 12,000 $\mathrm{gg}$ for $2 \mathrm{~min}$ and the DNA was eluted in $200 \mu \mathrm{L}$ ultrapure water $\left(65^{\circ} \mathrm{C}\right)$ by incubating for $10 \mathrm{~min}$ and then centrifuging at 12,000 $\mathrm{g}$ for $1 \mathrm{~min}$.

The cpDNA obtained was further purified using the Monarch ${ }^{\circledR} P C R$ \& DNA Cleanup Kit (NEB). The purification process was carried out following the manufacturer's instructions.

Method S4. Quality control and quantitation of the isolated DNA

The DNA was quantified using a Quantus ${ }^{\mathrm{TM}}$ Fluorometer with fluorescent dye. The analysis was carried out following the manufacturer's instructions and a blank value was always measured. The purity of the DNA samples was evaluated based on the $260 / 280$ and $260 / 230$ absorption ratios with a DS-11+ Spektro-photometer (DeNovix Inc.).

Method S5. Library preparation and sequencing

For the library preparation $5 \mathrm{ng}$ purified DNA and the Nextera ${ }^{\mathrm{TM}}$ DNA Flex Library Prep 24 Samples (Illumina) was used. The process was carried out following the manufacturer's instructions. Furthermore, the fragment lengths were checked by capillary gel electrophoresis (Thermofischer, bioanalyzer). It was necessary to use a high sensitivity chip to detect a signal. The process was carried out following the manufacturer's instructions. The final concentration of the library was $6 \mathrm{pm}$ and was spiked with $1 \%$ PhiX (illumina) as an internal standard. Two sequence runs were performed, one with a MiSeq Reagent Nano Kit v2 (0,5 Gb, Illumina) and 4 samples and the other with a MiSeq Reagent Kit v2 (7,5 Gb, Illumina) and 20 samples.

Method S6. Data processing and assembly 
The sequenced reads were trimmed to remove the adapter sequences, low quality reads ( $<16 Q S)$, reads shorter than $10 \mathrm{bp}$ and ambiguous bases with more than 10 consecutive bases within a read. The reads were trimmed and mapped to a reference genome sequence from NCBI (KT963008.1) to create consensus sequences for each walnut cultivar, using the CLC Genomics Workbench 11.0 software from QIAGEN. We compared the total consensus sequences among themselves using the Integrative Genomics Viewer 2.5.0 software to discover potential SNPs, deletions and inserts. 


\section{References}

(1) Oh, H.; Seo, B.; Lee, S.; Ahn, D.-H.; Jo, E.; Park, J.-K.; Min, G.-S. Two complete chloroplast genome sequences of Cannabis sativa varieties, Mitochondrial DNA. Part A, DNA mapping, sequencing, and analysis. 2016, 27, pp. 2835-2837.

(2) Fischer, M., project report “Food Profiling" Funding reference number: 2816500914.

(3) Mariotti, R.; Cultera, N. G. M.; Díez, C. M.; Baldoni, L.; Rubini, A. Identification of new polymorphic regions and differentiation of cultivated olives (Olea europaea L.) through plastome sequence comparison, BMC Plant Biology. 2010, 10, pp. 1-13.

(4) Tang, J.; Xia, H.'a.; Cao, M.; Zhang, X.; Zeng, W.; Hu, S.; Tong, W.; Wang, J.; Wang, J.; Yu, J.; Yang, H.; Zhu, L. A comparison of rice chloroplast genomes, Plant physiology. 2004, 135, pp. 412-420.

(5) Khan, A.; Khan, I. A.; Heinze, B.; Azim, M. K. The Chloroplast Genome Sequence of Date Palm (Phoenix dactylifera L. cv. 'Aseel'), Plant Mol Biol Rep. 2012, 30, pp. 666-678.

(6) Khan, A. L.; Asaf, S.; Lee, I.-J.; Al-Harrasi, A.; Al-Rawahi, A. First chloroplast genomics study of Phoenix dactylifera (var. Naghal and Khanezi). A comparative analysis, PloS one. 2018, 13, e0200104.

(7) Kahlau, S.; Aspinall, S.; Gray, J. C.; Bock, R. Sequence of the tomato chloroplast DNA and evolutionary comparison of solanaceous plastid genomes, Journal of molecular evolution. 2006, 63, pp. 194-207.

(8) Kane, N.; Sveinsson, S.; Dempewolf, H.; Yang, J. Y.; Zhang, D.; Engels, J. M. M.; Cronk. Quentin Ultra-barcoding in cacao (Theobroma spp.; Malvaceae) using whole chloroplast genomes and nuclear ribosomal DNA, American Journal of Botany. 2012, 99, pp. 320-329.

(9) Herrmann, L.; Haase, I.; Blauhut, M.; Barz, N.; Fischer, M. DNA-based differentiation of the Ecuadorian cocoa types $\mathrm{CCN}-51$ and Arriba based on sequence differences in the chloroplast genome, Journal of agricultural and food chemistry. 2014, 62, pp. 12118-12127.

(10) Tulecke, W.; McGranaham, G. The Walnut Germplasm Collection of the University of California, Davis, 13th ed.: Davis, California, July 1994.

(11) Bernard, A.; Barreneche, T.; Lheureux, F.; Dirlewanger, E. Analysis of genetic diversity and structure in a worldwide walnut (Juglans regia L.) germplasm using SSR markers, PloS one. 2018, 13, e0208021.

(12) Goodell, E. Walnuts for the Northeast, Arnoldia. 1983, 44, pp. 2-19.

(13) Szalatnay, D.; Kellerhals, M.; Frei, M.; Müller, U. Früchte, Beeren, Nüsse: Die Vielfalt der Sorten 800 Porträts, 1st ed.; Haupt: Berne, 2011.

(14) Lang, Erika G. E.; Mueller, Stefanie J.; Hoernstein, Sebastian N. W.; Porankiewicz-Asplund, Joanna; Vervliet-Scheebaum, Marco; Reski, Ralf (2011): Simultaneous isolation of pure and intact chloroplasts and mitochondria from moss as the basis for sub-cellular proteomics. In: Plant cell reports 30 (2), S. 205-215. 